\title{
BENTUK PENYAJIAN TARI RODAT DI JAMA'ATUL IHSAN 35 ILIR KOTA PALEMBANG
}

\author{
Oleh: \\ Qumala Sari
}

\begin{abstract}
ABSTRAK
Masalah dalam penelitian ini adalah bagaimanakah bentuk penyajian tari Rodat di Jama'atul Ihsan 35 ilir kota Palembang. Tujuan penelitian ini untuk mengetahui dan mendeskripsikan bentuk penyajian tari Rodat di Jama'atul Insan 35 ilir kota Palembang. Metode penelitian yang digunakan adalah metode deskriptif kualitatif. Penelitian ini dilakukan di Jama'atul Ihsan 35 lir kota Palembang. Sumber data dalam penelitian ini adalah Kgs. Muhammad Azmi Makmur MA dengan menggunakan teknik pengumpulan data yaitu observasi, wawancara, dan dokumentasi. Teknik analisis data yang digunakan adalah reduksi data, sajian data dan penarikan kesimpulan. Hasil penelitian menunjukan bahwa Tari Rodat merupakan kesenian tari tradisional yang bernapaskan Islam, dimana tari ini digunakan untuk misi berdakwah dan menyebarkan agama Islam karena dalam tari ini terdapat syair-syair pujian kepada Allah Swt dan Rasul-Nya. Tari ini berkembang seiring dengan tradisi memperingati Maulid Nabi di kalangan umat Islam di kota Palembang. Tari Rodat ditarikan dengan Leyek (menari sambil duduk). Tari ini biasanya ditarikan oleh kaum laki-laki yang berdominan anak-anak remaja. Penari tari Rodat berjumlah 12 orang atau penarinya harus berjumlah genap. Sedangkan pemusik dalam tari Rodat terdapat tiga bagian yaitu: penabuh umak, penabuh ningka, pengiring ningka. Tari Rodat ini biasanya tergabung dalam PPSA (Perkumpulan Pelajar Syarofal Anam). PPSA Jama'atul Ihsan sudah ada sebelum Indonesia mendapatkan kemerdekaannya yang didirikan oleh yang biasanya disapa dengan Anang Bintang yang merupakan orang asli dari Palembang. Tari Rodat ditampilkan pada acara memperingati Maulid Nabi, acara khitanan, acara peresmian nama dan hari-hari besar Islam.
\end{abstract}

Kata Kunci : Bentuk Penyajian, Tari Rodat,Palembang

\section{A. PENDAHULUAN}

Manusia dan kebudayaan merupakan kesatuan yang tidak dapat dipisahkan karena manusia merupakan pendukung kebudayaan sekalipun manusia akan mati, tetapi kebudayaan yang dimiliki akan diwariskan secara turun-temurun. Bangsa Indonesia merupakan salah satu negara yang terdiri dari berbagai suku yang memiliki keanekaragaman budaya. Keanekaragaman budaya di Indonesia dapat dilihat dari ritual masyarakat dan kesenian tradisional di setiap daerahnya. Kebudayaan merupakan suatu tindakan yang diciptakan dari kesepakatan bersama dalam bermasyarakat sehingga dapat dijadikan suatu ciri khas bagi masyarakat dan tempat masyarakat itu berada (dalam Laksana, 2011:14).

Kebudayaan memiliki beberapa unsur yang membentuknya yaitu bahasa, sistem pengetahuan, organisasi sosial, sistem teknologi, sistem ekonomi, sistem religi dan seni. Seni merupakan hasil karya yang diciptakan oleh seseorang yang memiliki nilai keindahan. Setiap bangsa, suku bangsa dan bahkan setiap diri manusia mempunyai seni. Demikian pula Indonesia yang dihuni oleh ratusan suku bangsa yang mempunyai kesenian yang tentunya beranekaragam. Sumatera Selatan sebagai salah satu daerah yang memiliki 
berbagai kesenian yang dipengaruhi oleh budaya Melayu, Cina dan Arab. Kesenian yang dipengaruhi tersebut tidak dalam satu jenis saja tetapi hampir menyentuh berbagai jenis seni, yaitu seni musik, seni rupa, seni teater dan seni tari.

Seni tari merupakan salah satu karya yang dituangkan melalui gerak terangkai yang berirama sebagai ungkapan ekspresi jiwa seseorang. Seni tari memiliki berbagai jenis, salah satunya berdasarkan pola garapannya terbagi menjadi dua yaitu tari kreasi baru dan tari tradisional. Tari tradisional tumbuh dan berkembang dalam lingkungan masyarakat umum atau rakyat yang bentuk gerak, irama, ekspresi dan rias busana yang sederhana serta sering disajikan secara tunggal, berkelompok atau berpasangan. Tari tradisional terbagi menjadi tiga kelompok yang salah satunya adalah tari tradisional rakyat artinya tari yang tumbuh dan hidup pada masyarakat diluar tembok istana. Tarian rakyat lebih dinilai sebagai ungkapan kehidupan rakyat pada umumnya berbentuk tarian bergembira maupun dimaksudkan untuk menyebarkan agama. Contoh dari tari tradisional rakyat yaitu tari Rodat dari Palembang. Tari Rodat merupakan kesenian tari yang bernapaskan Islam, dimana tari ini digunakan untuk misi berdakwah dan menyebarkan agama Islam karena dalam tari ini terdapat syair-syair pujian kepada Allah Swt dan Rasul-Nya. Tari yang termasuk dalam tari tradisional yang berkembang di Sumatera Selatan ini memiliki beberapa gerak dasar dan pola lantai yang hampir mirip dengan tari Saman dari Aceh. Tari ini pada mulanya hanya berbentuk seni membaca beberapa kitab sastra yang bernapaskan Islam berisi zikir, doa atau pujian terhadap Allah SWT dan Rasul-Nya. Tari ini berkembang seiring dengan tradisi memperingati Maulid Nabi di kalangan umat Islam di kota Palembang. Tari Rodat ini biasanya tergabung dalam PPSA (Perkumpulan Pelajar Syarofal Anam) Jama'atul Ihsan.

Jama'atul Ihsan merupakan grup Syarofal Anam yang terletak di 35 llir kota Palembang yang sudah lama ada dan diwariskan secara turun-temurun. Grup Syarofal Anam Jama'atul Insan sudah ada sebelum Indonesia mendapatkan kemerdekaannya yang didirikan oleh Kgs. Anang Bintang yang merupakan orang asli dari Palembang. Dengan adanya perkembangan zaman, maka mulai adanya grup Syarofal Anam yang lainnya, dan sekarang grup Syarofal Anam Jama'atul Ihsan dikelola oleh Kgs. Muhammad Azmi Makmur MA yang dipanggil dengan Ustadz Azmi ini sendiri mulai tergabung di Jama'atul Ihsan pada tahun 1981. Tari Rodat masih belum dikembangkan dan dimodifikasi. Pada tahun 1990 tari Rodat mulai dikembangkan, dimodifikasi dan banyak digunakan bukan hanya dalam acara memperingati Maulid Nabi, tetapi 
acara khitanan, acara peresmian nama dan hari-hari besar agama Islam. Tari Rodat ditarikan dengan Leyek (menari sambil duduk). Tari ini biasanya ditarikan oleh kaum laki-laki yang berdominan anak-anak remaja. Dalam tari Rodat terdapat lebih kurang 12 penari dan 8 pemukul Terbangan. Namun dalam 8 pemukul Terbangan terdapat 1 (satu) orang yang sebagai penyanyi atau pembaca kitab yang disebut Pembawa Hadi.

Namun, kehadiran tari Rodat ini sudah jarang sekali ditemukan di Palembang karena kurangnya minat dan perhatian serta peranan orang tua dan masyarakat untuk menyarankan anakanaknya ikut serta mencintai dan melestarikan tari Rodat. Anak-anak ataupun remaja lebih mendominasi kesenian dari luar Indonesia, itu dikarenakan pola pikir mereka yang menganggap kesenian luar lebih modern dan populer selain itu ada juga yang terbentur dengan kegiatan sekolah. Apabila tari Rodat tidak terus dilestarikan, maka akan menghilang dan tidak diketahui keberadaannya lagi. Sehingga generasigenerasi muda tidak akan mengetahuinya dan bahkan kesadaran mereka dalam melestarikan tari ini akan menurun.

\section{B. METODE PENELITIAN}

Menurut Sugiyono (2013:3), metode penelitian adalah cara-cara ilmiah untuk mendapatkan data dengan tujuan dan kegunaan tertentu tanpa mengubah susunan pelaksanaannya. Jenis penelitian yang diambil adalah penelitian kualitatif dengan menggunakan metode deskriptif.

Sugiyono (2013:13) mengatakan penelitian kualitatif merupakan metode baru yang proses penelitiannya lebih bersifat seni (kurang terpola) dan hasil penelitian lebih berkenaan dengan pendapat terhadap data yang ditemukan di lapangan. Menurut Tuwu (dalam Karmila, 2013:21) bahwa metode deskriptif adalah metode untuk menggambarkan suatu keadaan yang dilihat, didengar dan dirasakan pada waktu penelitian dilakukan dan menjelajah penyebab gejala permasalahan kemudian dituangkan ke dalam bentuk tulisan. Sedangkan menurut Arikunto (2013:3) metode deskriptif merupakan metode untuk menyelidiki suatu keadaan, kondisi atau halhal yang dibutuhkan, kemudian hasilnya sesuai dengan apa yang ada di lapangan dan dipaparkan dalam bentuk laporan penelitian.

Penelitian ini bersifat menggali, mengelolah, menyelidiki dan menafsirkan serta menguraikan beberapa fenomena untuk mencari faktor apa atau situasi bagaimana yang menyebabkan timbulnya suatu peristiwa tertentu. Semua data yang telah didapat dalam penelitian ini secara berurutan akan dijelaskan secara terperinci sesuai dengan fakta dan kenyataan yang 
didapat di lapangan baik yang dilihat, didengar, dicatat, didokumentasikan, dan selanjutnya dianalisis kemudian disimpulkan sehingga dapat tercapainya tujuan yang diinginkan dalam penelitian ini. Objek dalam penelitian ini adalah tari Rodat yang terdapat di Jama'atul Ihsan 35 llir Palembang. Dengan mengamati proses latihan grup Syarofal Anam di Jama'atul Ihsan. Sedangkan yang menjadi instrumen dalam penelitian ini adalah peneliti sendiri karena dalam penelitian kualitatif kedudukan peneliti cukup rumit, peneliti sebagai perencana, pelaksana, mengumpulkan data, analisis, penafsiran data dan pada akhirnya menjadi pelopor hasil penelitian.

Teknik pengumpulan data merupakan langkah yang paling utama dalam penelitian karena utama dari penelitian adalah mendapatkan data. Pengumpulan data dapat dilakukan dalam berbagai setting, berbagai sumber dan cara. Penelitian ini menggunakan teknik pengumpulan data observasi, wawancara, dan dokumentasi. Dalam penulisan ini, penulis menggambarkan asal-usul tari, penari, gerak tari, pola lantai, musik pengiring, busana (kostum) dan area pentas yang terdapat dalam tari Rodat.

\section{PEMBAHASAN DAN HASIL PENELITIAN}

\section{Sejarah Tari Rodat di Palembang}

Agama Islam masuk ke Indonesia tidak langsung dari daerah asalnya, yaitu Arab Saudi, namun melalui Teluk Persi, India (Gujarat), dan Cina. Bahwa Islam masuk ke Indonesia tidak hanya melalui satu pintu yaitu daerah Jawa saja, tetapi dibeberapa tempat lainnya, seperti Aceh, Sumatera Utara, Sumatera Barat, Riau, Makassar, Palembang dan kota-kota lain terutama kota yang memiliki pelabuhan laut (sungai), antarnusa ataupun antarnegara (Sedyawati, 2009:93).

Agama Islam sendiri masuk ke Sumatera pada pertengahan abad ke-16. Pada waktu agama Islam telah berkembang pesat di Nusantara pada abad ke-18-19, Palembang menjadi pusat syiar agama Islam dan juga pusat sastra agama. Dengan kata lain, Palembang sejak awal berdiri selalu menjadi pusat syiar agama, mulai dari Budha sampai Islam. Dalam perjalanannya, hunian yang bernama Sriwijaya itu lama kelamaan tumbuh dan berkembang menjadi sebuah kota pelabuhan sungai. Sebagai kota pelabuhan, kota Palembang bercorak internasional sejak masih disebut Sriwijaya. Orang dengan latar belakang kebudayaan, warna kulit dan keyakinan agama yang berbeda-beda bertemu di Bandar ini sudah berabad-abad lamanya. Berdasarkan catatan sejarah tinggalan budayanya, tercatat perdagang dari Arab, Parsi, India, Cina dan Jepang serta terakhir Eropa 
(Inggris dan Belanda) datang berniaga di Palembang (Utomo, 2005:3).

Dua bangsa yang hingga kini mendiami Palembang dan telah beranak pinak adalah Arab dan Cina, kemudian melakukan perkawinan campuran dengan penduduk pribumi dan mulai mengikuti gaya hidup lokal. Awal kemunculannya tidak dapat diketahui secara pasti, namun penyebaran agama Islam didukung dengan adanya tempat-tempat pesantren dan grupgrup Syarofal Anam yang salah satunya yaitu Perkumpulan Pelajar Syarofal Anam Jama'atul Ihsan yang berdiri sebelum Indonesia mendapatkan kemerdekaannya pada tahun 1941. Ketika Jama'atul Ihsan ada, maka munculnya kesenian Islam yaitu Rodat di daerah 35 llir. Grup ini selalu melakukan pertunjukan seni Islam yaitu kesenian Rodat yang jenis pertunjukannya berupa bernyanyi bersama dengan diiringi alat musik Terbangan atau Rebana. Teks yang dinyanyikan berupa puji-pujian kepada Allah SWT dan Rasul-Nya yang berasal dari kitab Berzanji. Kata Rodat sendiri berasal dari kata Irodat, salah satu sifat Allah yang berarti berkehendak. Maksud pemberian nama itu adalah agar manusia selalu berkehendak untuk mendekatkan diri kepada Allah SWT. Ada lagi yang mengatakan berasal dari kata Raudah, yaitu taman nabi yang terletak di Masjid Nabawi, Madinnah (Wawancara dengan Kgs.
Muhammad Azmi Makmur MA, tanggal 13 Juni 2015).

Kemudian secara turun-temurun Jama'atul Ihsan diurus oleh keturunan Kgs. Anang Bintang. Pada tahun 1981, Kgs. Muhammad Azmi Makmur MA yang biasa disapa dengan Ustadz Azmi mulai bergabung di Jama'atul Ihsan, tetapi acara memperingati Maulid Nabi Muhammad SAW masih tetap sama dengan sebelumnya hanya membaca Kitab Berzanji dengan diringi musik dari alat musik Terbangan atau Rebana. Kesenian ini berkembang seiring dengan tradisi memperingati Maulid Nabi di kalangan umat Islam agar yang sesuai dengan perkembangan zaman, maka kesenian ini tetap ada dan dapat terus dinikmati, maka pada tahun 1990 kesenian Rodat dikembangkan dan dimodifikasi dengan penambahan gerak-gerak yang beberapa gerakannya mirip dengan gerakan sholat. Sehingga kesenian Rodat sekarang lebih dikenal dengan tari Rodat. Kemudian tari Rodat tidak hanya dalam acara memperingati Maulid Nabi Muhammad SAW saja, tetapi pada acara khitanan, acara peresmian nama dan hari-hari besar agama Islam lainnya. Dengan berkembangnya kesenian Rodat menjadi tari Rodat yang merupakan tari yang mengiringi pembawa Hadi dari Jama'atul Ihsan, maka mulailah bermunculan grup Syarofal Anam yang lain dengan menciptakan tari Rodat yang gerakan tariannya hampir berbeda dan juga 
busana yang dikenakan baik dari corak maupun warnannya juga berbeda, maka tari Rodat di Jama'atul Ihsan merupakan tarian yang memulai munculnya grup Syarofal Anam yang lain dengan gerak dan busana yang berbeda dari satu grup dengan grup yang lain sesuai ciri khas mereka masingmasing yang terdapat di kota Palembang.

\section{Grup Syarofal Anam Jama'atul} Ihsan

Penyebaran agama Islam didukung dengan adanya tempat-tempat pesantren dan grup-grup Syarofal Anam, salah satunya yaitu Jama'atul Ihsan yang berdiri sebelum Indonesia mendapatkan kemerdekaannya pada tahun 1941. Grup Jama'atul Ihsan ini didirikan oleh Kgs. Anang Bintang yang merupakan orang asli Palembang. Kemudian secara turuntemurun Jama'atul Ihsan diurus oleh keturunan Kgs. Anang Bintang.

Pada tahun 1981, Kgs. Muhammad Azmi Makmur MA yang biasa disapa dengan Ustadz Azmi mulai bergabung di Jama'atul Ihsan, pada saat itu diurus oleh M. Ali Hanafiah Arif (Kyai Maning) kemudian Kgs. Arifin Khadir. Ustad Azmi dapat menjadi pengurus Jama'atul Ihsan dikarenakan Kgs. Arifin Khadir merupakan adik dari ibu Ustad Azmi sendiri, maka Jama'atul Ihsan diturunkan kepada Ustad Azmi. Pada tahun 1996 sampai sekarang, Ustad Azmi menjadi pengurus Jama'atul
Ihsan. Jama'atul Ihsan merupakan grup Syarofal Anam yang pertama dan kemudian mulailah bermunculan grup Syarofal Anam yang lainnya di Palembang dan sekarang Jama'atul Ihsan menjadi grup yang terus melestarikan tari Rodat yang setiap malam minggu, anak-anak latihan tari Rodat yang diajarkan langsung.

\section{Bentuk Penyajian Tari Rodat}

Menurut Djelantik (dalam Elvandari, 2014:63), sebuah penampilan karya seni terdapat susunan yang menjadi aspek yang menyangkut keseluruhan dari karya itu dan meliputi penari, gerak tari, pola lantai, musik pengiring, busana (kostum) dan area pentas serta juga peranan masing-masing bagian dalam keseluruhan itu. Semua keseluruhan itu dapat disebut bentuk penyajian tari. Seperti halnya, tari Rodat yang fokus membahas gerak tari, pola lantai, penari, busana (kostum yang digunakan), musik pengiring dan area pentas.

\section{a) Penari}

Suatu jenis tari bila dibagi/dikelompokan berdasarkan bentuk komposisinya atau koreografi yang dijelaskan oleh Sartono (2008:19) terbagi menjadi tiga bentuk, yaitu tari tunggal/solo, tari berpasangan dan tari kelompok.

Berdasarkan pengelompokan tersebut, tari Rodat memiliki jumlah penari yang lebih dari tiga orang, maka tari ini 
termasuk ke dalam jenis tari kelompok yang membutuhkan kekompakan dan keseragaman dalam penampilannya. Dalam tari Rodat penari harus berjumlah genap seperti berjumlah 12 penari, tetapi tidak boleh kurang dari 8 penari karena akan terlihat kurang kekompakannya ketika tarian ini ditampilkan. Tari Rodat biasanya ditarikan oleh kaum laki-laki yang berdominan anak-anak remaja yang berusia antara 9-16 tahun atau yang belum akhir baligh.

\section{b) Gerak Tari}

Membahas tentang sebuah tarian, secara tidak langsung juga akan membahas mengenai berbagai gerakan yang terdapat di dalam tari tersebut. Menurut Soedarsono (dalam Elvandari, 2014:68), gerak memiliki dua macam yaitu gerak maknawi merupakan gerak yang memiliki arti atau makna tertentu sedangkan gerak murni adalah gerak yang tidak mengandung arti, namun masih mengandung unsur keindahan gerak.

Dalam penelitian yang peneliti lakukan, gerak yang terdapat dalam tari Rodat merupakan beberapa gerakan yang terlihat menyerupai gerakan-gerakan dalam sholat seperti posisi para penari dalam tarian ini duduk menyerupai duduk dalam solat yaitu duduk bersimpuh, ada gerakan tangan seperti berdoa, geraknya bersifat statis dan gerakannya digarap tidak dimaksudkan untuk menggambarkan sesuatu, serta gerak-gerak dasarnya adapula yang sama dengan tari Saman dari Aceh. Oleh karena itu, gerakan tari ini cenderung diulang-ulang dan tidak terlalu berpedoman pada tari yang baku dan rumit.

Gerakan dalam tari Rodat tidak memiliki nama yang dipatenkan atau disahkan, tetapi gerakannya disesuaikan dengan pukulan pada alat musik Terbangan atau Rebana yang telah disusun untuk sebuah penampilan yaitu pembukaan, sihir (biasa), yahum, kincat, dan penutup.

\section{c) Pola Lantai}

Pola lantai sama halnya dengan desain lantai yaitu garis-garis yang lalui oleh para penari. Tari Rodat memiliki kesamaan dengan tari Saman dari Aceh pada beberapa gerak dasar, selain itu juga pada pola lantainya. Pola lantai pada tari Rodat memiliki satu pola lantai, yaitu garis lurus secara horizontal (ke samping kanan-kiri). Menurut Elvandari (2014:71), garis lurus berarti memberikan kesan/sifat sederhana tetapi kuat, tenang dan seimbang. Tari Rodat ditarikan dengan Leyek (menari sambil duduk). Tidak adanya perubahan dalam pola lantai sehingga menjadikan tari Rodat berbeda dengan tari-tarian lain yang ada di kota Palembang, dengan posisi duduk bersimpuh seperti dalam sholat pada agama Islam. 


\section{d) Musik Pengiring}

Musik merupakan salah satu unsur penting dalam sebuah pertunjukan seni, antara lain seperti seni vokal, seni teater dan bahkan seni tari. Dengan adanya musik dapat terciptanya sebuah karya yang indah sehingga dapat menggerakan jiwa para penonton. Musik dalam tari dapat diciptakan oleh penari sendiri baik dari pukulan tangan ke badan atau dari mulut dan ada pula dari luar penari seperti menggunakan alat musik.

Terbangan merupakan sinonim dari kata Rebana yang digunakan dalam lingkungan pemakai bahasa melayu. Terbangan merupakan alat musik yang terbuat dari bahan kayu dan pada satu sisi dipasang kulit hewan seperti kambing dan sapi. Badan terbangan dipasangi piringpiringan logam yang bisa berdencing dan dibunyikan dengan cara dipukul atau digoyangkan dengan tangan atau ditepuk dan jari-jari (dalam Sedyawati, 2009:92).

Musik pengiring tari Rodat terdapat tiga bagian (Penabuh Rebana) yaitu penabuh umak yaitu menggunakan tempo yang sedang dan lambat, penabuh ningka yang menggunakan tempo cepat sehingga membutuhkan tenaga yang ekstra untuk memainkan irama tersebut dan pengiring ningka yaitu membentuk irama yang selaras dengan tempo sedang dan lambat sesuai kecepatan tempo pada penabuh ningka.

Lantunan-lantunan dalam tari Rodat disebut Hadi. Kebanyakan teks lagu atau latunan-latunan tersebut diambil atau berdasarkan kitab Berzanji yang isinya menyebarkan ajaran moral Islam, menganjurkan umat untuk berbuat baik dengan mencontoh apa yang dikatakan atau dilakukan oleh Nabi Muhammad SAW.

\section{e) Busana}

Salah satu hal utama dari sebuah perlengkapan adalah kostum. Pada dasarnya, dalam sebuah penampilan penonton terlebih dahulu melihat penampilan kostum yang dikenakan sebelum melihat gerak-gerak para penari. Kostum yang digunakan harus nyaman dipakai dan enak dilihat oleh para penonton. Sehingga dalam pertunjukan, penonton dapat menikmati tidak hanya gerak, tetapi juga kostum yang sesuai dengan jenis tarian. Kota Palembang terdapat banyak grup Syarofal Anam yang kostumnya memiliki khas tersendiri.

Di Jama'atul Insan, kostum tari Rodat yang digunakan memiliki ciri khas seperti kostum Melayu yang menunjukan bahwa kota Palembang merupakan daerah yang masih identik dengan budaya Melayu selain Arab dan Cina, yaitu Tanjak (hiasan kepala), Telok Belango (baju yang dipakai), celana panjang, selendang dan kain yang terbuat dari tenun songket Palembang, kostum penabuh Rebana yaitu Tanjak, jas lengan panjang warna hitam, celana 
panjang warna hitam dan kain Songket khas Palembang.

\section{f) Area Pentas}

Area pentas tari Rodat dapat dilakukan di berbagai tempat, sesuai dengan acara yang bersangkutan. Apabila tari Rodat ingin dipertunjukan dalam suatu acara memperingati Maulid Nabi dan Harihari besar agama Islam maka Mesjid menjadi tempat tari Rodat ditampilkan. Bisa juga berbentuk pentas yang bernama majlas, yaitu kumpulan orang-orang yang membentuk lingkaran atau setengah lingkaran. Tari Rodat juga sering berfungsi untuk hiburan dalam acara khitanan dan acara peresmian nama.

Tari Rodat dapat ditampilkan kapan saja. Akan tetapi, berdasarkan hasil pengamatan peneliti, tari Rodat lebih sering ditampilkan pada pagi hari karena acaraacaranya dimulai pada pagi hari seperti Maulid Nabi, Isra Mi'raj, khitanan, peresmian nama, dan hari-hari besar agama Islam lainnya.

\section{SIMPULAN}

Grup Syarofal Anam yang terdapat di Palembang salah satunya yaitu Jama'atul Ihsan di 35 llir kota Palembang yang sudah lama ada dan diwariskan secara turuntemurun. Grup Syarofal Anam Jama'atul Insan sudah ada sebelum Indonesia mendapatkan kemerdekaannya yang didirikan oleh Kgs. Anang Bintang yang merupakan orang asli dari Palembang pada tahun 1941. Sekarang grup Syarofal Anam Jama'atul Ihsan dikelola oleh Kgs. Muhammad Azmi Makmur MA yang dipanggil dengan Ustadz Azmi ini sendiri mulai tergabung di Jama'atul Ihsam pada tahun 1981, tetapi pada tahun 1996 Ustad Azmi mulai mengurus Jama'atul Ihsan hingga sekarang. Kesenian Rodat digunakan untuk misi berdakwah dan menyebarkan agama Islam serta masih belum dikembangkan dan dimodifikasi.

Pada tahun 1990 kesenian Rodat mulai dikembangkan dan dimodifikasi menjadi sebuah tari. Tari Rodat merupakan tari tradisional yang bernapaskan Islam, karena dalam tari ini terdapat syair-syair pujian kepada Allah Swt dan Rasul-Nya. Kata Rodat berasal dari kata Irodat, salah satu sifat Allah yang berarti berkehendak. Maksud pemberian nama itu adalah agar manusia selalu berkehendak untuk mendekatkan diri kepada Allah SWT. Ada lagi yang mengatakan berasal dari kata Raudah, yaitu taman nabi yang terletak di Masjid Nabawi, Madinnah. Tari ini pada mulanya hanya berbentuk seni membaca beberapa kitab sastra yang bernapaskan Islam berisi zikir, doa atau pujian terhadap Allah SWT dan Rasul-Nya. Tari ini berkembang seiring dengan tradisi memperingati Maulid Nabi di kalangan umat Islam di kota Palembang. Tari ini memiliki 
penari berjumlah lebih kurang 12 orang atau penarinya harus berjumlah genap dan biasanya ditarikan oleh kaum laki-laki yang berdominan anak-anak remaja berusia 9-16 tahun. Gerak yang terdapat di dalam tari Rodat yaitu pembukaan, sihir (biasa), yahum, kincat dan penutup, serta memiliki satu pola lantai yaitu garis lurus secara horizontal, dimana tari Rodat ditarikan dengan Leyek (menari sambil duduk). Sedangkan pemusik dalam tari Rodat terdapat tiga bagian, yaitu penabuh umak, penabuh ningka, pengiring ningka. Dalam tari Rodat, kostum yang digunakan yaitu Tanjak (hiasan kepala), Telok Belango (baju yang dipakai), celana panjang, selendang dan kain yang terbuat dari tenun songket Palembang. Tari Rodat dapat dilakukan di berbagai tempat, sesuai dengan acara yang bersangkutan. Acara-acara tersebut antara lain Maulid Nabi, Isra Mi'raj, khitanan, peresmian nama, dan hari-hari besar Islam lainnya.

\section{DAFTAR PUSTAKA}

Elvandari, Evita. 2014. Koreografi (Proses Penciptaan Tari). Palembang : Universitas PGRI Palembang.

Laksana, Robert Budi, Dkk. 2011. Bahan Ajar Sosiologi Tari. Palembang : Universitas PGRI Palembang.

Sartono. 2008. Pengantar Pengetahuan Kesenian. Palembang : Universitas PGRI Palembang.

Sedyawati, Edi, Dkk. 2009. Sejarah Kebudayaan Indonesia: Seni Pertunjukan dan Seni Media. Jakarta : PT. Rajagrafindo Persada.

Utomo, Bambang Budi. 2005. Perkembangan Kota Palembang dari Wanna Sriwijaya Menuju Palembang Modern. Palembang : Pemerintah Daerah Kota Palembang Paguyuban Masyarakat Peduli Musi. 